\title{
TINAGL1 wt Allele
}

National Cancer Institute

\section{Source}

National Cancer Institute. TINAGL1 wt Allele. NCI Thesaurus. Code C158392.

Human TINAGL1 wild-type allele is located in the vicinity of 1 p35.2 and is approximately $11 \mathrm{~kb}$ in length. This allele, which encodes tubulointerstitial nephritis antigen-like protein, may be involved in the modulation of ligand-dependent signaling. 